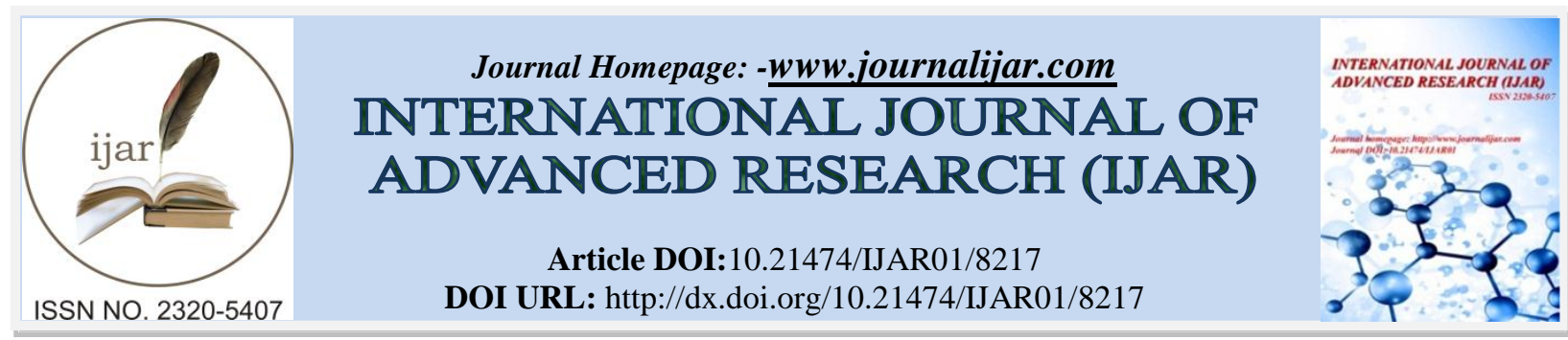

RESEARCH ARTICLE

\title{
DEVELOPING 3D INSTRUCTIONAL MEDIA TAKBULTA FOR THE SUB-THEME OF "POTENTIAL SOURCES OF ENERGY IN INDONESIA".
}

Eko Susetyarini ${ }^{1}$, Kuncahyono $^{2}$, Rahmita Rizky Fitriasari ${ }^{2}$ and Ahmad Fauzi ${ }^{1}$.
1. Department of Biology Education, University of Muhammadiyah Malang, Indonesia.
2. Primary School Teacher Education Department, University of Muhammadiyah Malang, Indonesia.

\section{Manuscript Info}

Manuscript History

Received: 16 October 2018

Final Accepted: 18 November 2018

Published: December 2018

\section{Key words:-}

Instructional media, thematic learning, takbulta, primary school.

\section{Abstract}

The availability of thematic, innovative, and interesting instructional media is deemed as a significant attempt for quality improvement on instructional activities in schools. In this current research, Takbulta (Kotak Timbul Bercerita - a telling embossed box) has been developed as instructional media for the sub-theme of "Potential Resources of Energy in Indonesia." The sub-theme is one of several themes learnt by the fourth graders. This research constituted Research and Development model (R\&D), which was previously advanced by Borg and Gall. The research phases encompassed research and data collection; planning the educational product; developing the product's preliminary form; initial field testing; the first revision of main product; main field testing; operational product revision; operational field testing; and final product revision. The results of validation gained from the media expert, material expert, and instructional practitioner 1 and 2 respectively signified $94.2 \%, 83.3 \%, 94.2 \%$, and $94.2 \%$. With respect to the aforementioned results, it has been explicated that Takbulta is appropriate to use. Moreover, the implementation of the media on the instructional activities shows that Takbulta has resulted in higher level of the students' active participatory during the instructional activities.

Copy Right, IJAR, 2017,. All rights reserved.

\section{Introduction:-}

Primary school education is the first phase of compulsory education system that must be fulfilled by children(Hayes, 2010). This phase is the most crucial period for individual education. In this period, furthermore, children are going to learn and gain breadth of basic science and knowledge (Doğan \& Sezer, 2010).Besides, all primary schools are responsible for character building, including raising children's sense of punctuality (Romanova, 2016) in addition to providing assistance and guidance for their social, physical, and emotional developments (Beard, 2018).

Apart from the crucial roles, piloting instructional activities in primary schools has several challenges to deal with, encompassing that: the primary school students tend to be unfocused and inattentive; they often perform distressing actions; and they tend to be hyperactive during the instructional activities (Merrell \& Thymms, 2012). Moreover, in terms of cognitive level, the primary school students are still categorized to be in a concrete operational level (Astuti, 2018; Ghazi \& Ullah, 2015; Simatwa, 2010). Learning must be able to package abstract concepts into

Corresponding Author:-Eko Susetyarini.

Address:-Department of Biology Education, University of Muhammadiyah Malang, Indonesia. 
concrete things and can be presented to the class(Brown, McNeil, \& Glenberg, 2009; Fauzi, Corebima, \& Zubaidah, 2016; Fauzi \& Ramadani, 2017; Knippels, 2002; Lindsay, 2011); this effort will be more difficult for teacher who have students that still in the concrete operational stage. Furthermore, the instructional activities in primary schools should take into account the students' metacognition which is yet to develop optimally. In other words, the students' ability to take the most effective strategy for learning and their awareness of the urgency of instruction have not been well-developed optimally (Cera, Mancini, \& Antonietti, 2013; Ismael, 2015).

Some countries have made some efforts for designing primary education system as it is supposed to be for the sake of national educational purposes. In Indonesia, instructional activities in primary schools are designed in thematic instructional system (N. Ain \& Rahutami, 2018; Hamruni \& Istiningsih, 2017). Thematic instruction refers to any instruction which relates and integrates any of general knowledge and information into one main theme. By this instructional model, the instructional activities are shown to be more natural as the knowledge and information engaged seem to be non-fragmented (Nurul Ain, 2017; Okoro \& Okoro, 2016). Besides, thematic instruction is also assumed to be more effective than that of the conventional one. The main reason highlighting the comparison of which is that students are facilitated to explore and observe some phenomena or issues from different perspectives in addition to interlinking all of them to several related disciplines (Tomljenovi \& Novakovi, 2012). Also, thematic instruction is declared as an effective way to improve students' perspective on the instruction itself and maintain their joyful learning about new things (Tessier, Suny, Tessier, \& Delhi, 2015).

Nevertheless, some conditions are also presumed as triggering factors that might cause the primary schools to be less optimal in achieving the targeted purposes. The conditions encompass students' intrinsic factors (Asfani, Suswanto, \& Wibawa, 2016; Bulent, 2015; Rasul \& Bukhsh, 2011) as well as learning facilities in schools (Ekundayo, 2012; Habibullah \& Ashraf, 2013; Hasbullah, Yusoff, Ismail, \& Vitasari, 2011). This portrayal refers to the results of observation piloted in two primary schools in Jombang, Indonesia during November 2017. With reference to the observational results, the students from both schools varied in terms of learning achievement level. In accordance with the results of observation and interview with the teachers from both schools, there were some factors differentiating the students' academic achievements which had been collected. The key information highlighted was that there was found different learning facilities for supporting instructional activities and different students' interest in the instruction.

In primary school level with low level of achievement, the instruction is centered on teachers. The instruction, further, is also assisted by LCD and laptop. Besides, the teachers have not been well assisted with any innovative media during the instruction. The teacher-centered instruction with lack of instructional media assistance would make the students less motivated in learning (Jony, 2016; Naz \& Akbar, 2010; Smit, de Brabander, \& Martens, 2014). Such a condition would lead to lack of engagement from the students during the instruction (Kui Xie, Vance Durrington; Yen, 2011; Saeed \& Zyngier, 2012). Low students' interest and motivation towards the instruction are viewed as the factors that are associated with low students' academic achievement (Gunuc, 2014; Veiga, Burden, Appleton, Taveira, \& Galvão, 2104).

A specific way to take to upgrade the students' interest in the instruction is by making use of innovative media (Muteheli, 2017; Naz \& Akbar, 2010). The statement has been supported by a couple of researches reporting that the instructional media development and provision could improve the students' motivation in learning (Puspitasari, Putri, \& Wuryani, 2018; Widiansyah, Indriwati, Munzil, \& Fauzi, 2018). In addition, the availability of instructional media has been said to positively improve other instructional parameters; one of which is students' practical skills (Rajendra \& Sudana, 2018). Indeed, the availability of instructional media has been an urgent need for instruction, especially in primary school level (Manjale \& Abel, 2017).

Unfortunately, there has been still lack of accessibility of innovative media for primary schools. The statement is reflected by the result of interview with the primary school teachers in Jombang, Indonesia. The teachers stated that they had found themselves difficult to find appropriate instructional media for thematic instruction. The limited time the teachers had was considered as the contributing factor that resisted them to design an innovative instruction. For that reason, innovative media development for primary school teachers, especially the one that meets the characteristics of thematic instruction and primary school students, is of urgency to bring into reality.

In this current research, an innovative instructional media was developed as an attempt to optimize the students' learning process in schools. The media, further, was designed to facilitate the students during instructional activity 
with one of sub-themes stipulated in the curriculum. In addition, the instructional media was also supposed to be embodied with a specific characteristic that differed from other common media. The characteristic, in this point, referred to a state of being more than 2 dimensional, by combining audio and visual media. In addition, the availability of the media was also supposed to help the teachers deliver the materials to their primary school students. Hereinafter, the interactive media, as explained, was named as Takbulta (Kotak Timbul Bercerita - a telling embossed box).

\section{Research Method:-}

This current research was Research and Development model (R\&D), which aimed at developing Takbulta media in behalf of instruction for the fourth graders under theme 9, entitled "My Magnificent Homeland," with the sub-theme of "Potential Sources of Energy in Indonesia." The development, further, was performed through nine-phase model of research and development proposed by Borg \& Gall(1983).

\section{Research and Information Collecting:-}

In this phase, need analysis was administered by collecting some data in the targeted field. The analysis took place at two primary schools in Jombang, Indonesia. Both of the schools were attended by students with varying academic achievement. The one with higher-achievers was located in the center of the city; while the one with lower-achievers was in the countryside. In this phase, two instruments were used for data collection, observation and interview. The observation and interview guidance was taken from the modified version of Sugiyono(2017). In the observation guidance, there were eight items which were categorized into two specific aspects, comprising instruction (5 items) and students' responses ( 3 item). Meanwhile, for the interview guidance, there were 10 items which were subdivided into two major categories, instruction ( 7 items) and media (3 items). This phase was piloted on November 2017.

\section{Planning:-}

In this phase, there were some actions performed, such as determining instructional purposes, steps to take for designing media, and necessary tools, in addition to planning a series of activities for Takbulta media development.

\section{Developing Preliminary Form of the Product:-}

The initial product that had been set in plan during the planning phase was developed in this phase. Besides, the instructional materials along with the instruments for evaluation were also prepared. The main product of development, further, was validated by the experts of media and material, together with the educational practitioners. The expert of material was a lecturer of instructional material course; the expert of instructional media was a lecturer of instructional media course; and the educational practitioners were primary school teachers from two different schools. All of them, further, were to complete the questionnaire consisting of responses and judgments towards Takbulta media, the target of development. The questionnaire, moreover, was developed based on Sugiyono(2017). The questionnaire for the expert of instructional media comprised three main aspects: (1) procedures of using the instructional media, (2) attractiveness; and (3) instruction. As for the expert of material, there were two aspects included in the questionnaire: (1) instruction and (2) instructional material. The questionnaire for educational practitioners covered two main aspects, namely: (1) instructional material and (2) instructional media. Each of the mentioned aspects consisted of several indicators; each of which embraced four scales of criteria, to name (1) strongly disagree, (2) disagree, (3) agree, and (4) strongly agree.

In this phase, two types of data were collected, namely; quantitative and qualitative data. The qualitative data were in the form of notes from validators; while the quantitative data were in the form of scores from the validators. Next, the qualitative data were analyzed descriptively, and the quantitative data were analyzed by means of formula (1). The result of the analysis, further, was used as the basis of validity of Takbulta media. The validity level was based on the qualifications proposed by Sugiyono(2017). The qualifications for the validity level are shown in Table 1.

Table 1:-The Qualifications of Validity Level and Product Appropriateness

\begin{tabular}{|c|c|c|}
\hline Percentage(s) (\%) & Validity Level(s) & Note(s) \\
\hline $85<$ the score $\leq 100$ & strongly valid & no revision \\
\hline $65<$ the score $\leq 85$ & valid & wo revision \\
\hline $50<$ the score $\leq 65$ & fairly valid & with revision \\
\hline $35<$ the score $\leq 50$ & less valid & with revision \\
\hline $20<$ the score $\leq 35$ & poorly valid & \\
\hline
\end{tabular}




\section{Preliminary Field Testing:-}

In this phase, the initial product was tested on the limited number of students, signifying six students in total in each primary school. The primary school participating in the test was SDN Kedawong in Jombang. The students who were participating in the tests, moreover, were interviewed to probe their responses, suggestions, and comments regarding the use of Takbulta.

\section{Main Product Revision:-}

All comments and suggestions generated from the expert of instructional material, the expert of instructional media, the educational practitioners, and the students were used as the basis for main product revision.

\section{Main Field Testing:-}

After the first revision on the main product, the product was then tested to the fourth graders of the primary schools. The involved students were to fill out the questionnaire containing their responses to Takbulta they had utilized during the previous instruction. The questionnaire was developed based on Sugiyono(2017), and it included two major aspects, covering (1) instructional material and (2) instructional media.

\section{Operational Product Revision:-}

The data collected from the students' responses in Main Field Testing phasewere utilized as the basis of the second revision for Takbulta media.

\section{Operational Field Testing:-}

After the second revision, Takbulta was tested to two different schools in Jombang. Both of the schools respectively represented the one with higher academic achievement and the other one with lower academic achievement. Each of the schools, further, comprised $30-40$ fourth-grade students. The students were positioned as the subjects of the Operational Field testing. During the testing, the researchers were observing the instructional activities and asking the students to personally give their comments on the instructional media used, Takbulta, by means of questionnaire. The testing was conducted on September, specifically in odd semester of academic year 2018/2019. The questionnaire was the same as that in Main Field Testingphase.

\section{Final Product Revision:-}

After the Operational Field Testing was done, the data collected in the phase were used as the basis of revision on the finalized product.

\section{Results and Discussion:- \\ Research and Information Collecting:-}

In this phase, some information was collected. The information included that: (1) the teachers were infrequently making use of instructional media to deliver the materials; (2) the teachers only utilized video as the instructional media which was fitted to the instructional materials; (3) the instruction was still teacher-centered, by means of lecturing, question-and-answer, task-based, and discussion methods; and (4) the students were shown to be passive and inattentive during the instructional activities. Furthermore, the results of interview with the teachers on November 28, 2017 complemented the results of preliminary observation on the students' needs. During the instruction, the teachers were shown to be less creative to find any varying use of the instructional media, despite the technological supports provided, like LCD and the laptop. In addition, the instructional media and sources were assumed to be very limited, specifically the one for thematic instruction. Besides, all this time, the teachers were only using the textbooks, provided by the government, as the main instructional media and sources.

\section{Planning:-}

In this phase, theme, basic competence (BC), and indicators of learning achievement were determined. Theme 9, entitled "My Magnificent Homeland" with the sub-theme "Potential Sources of Energy in Indonesia" instruction 1, was selected as the main theme for the instructional media under development. The theme covered some basic competences, namely: 1) Natural Sciences on BC 3.5 and 4.5; 2) Social Sciences on BC 3.1 and 4.1; and 3) Bahasa Indonesia on $\mathrm{BC}$ 3.3. and 4.3. Next, the indicators of the learning achievements are shown in Table 2. The next stage was to design a product of interactive instructional media, Takbulta. The design of the product was in the form of box with embossed miniatures of mounts, farmlands, houses, and other components. This design, in addition, was also voice-assisted resembling someone telling a story. 
Table 2:-The Indicators of Learning Achievement

\begin{tabular}{|c|c|}
\hline Discipline(s) & Details of Indicators \\
\hline \multirow[t]{3}{*}{$\begin{array}{l}\text { Natural } \\
\text { Sciences }\end{array}$} & $\begin{array}{l}\text { 3.5.1 To mention at least } 3 \text { sources of energy which are commonly used for daily life, with the sense } \\
\text { of caring }\end{array}$ \\
\hline & $\begin{array}{l}\text { 3.5.2 To mention at least } 2 \text { relationships between water and electricity as sources of energy for daily } \\
\text { life }\end{array}$ \\
\hline & $\begin{array}{l}\text { 4.5.1 To create a mind-map about interconnectedness between water and electricity as sources of } \\
\text { energy for daily life }\end{array}$ \\
\hline \multirow[t]{3}{*}{$\begin{array}{l}\text { Social } \\
\text { Sciences }\end{array}$} & $\begin{array}{l}\text { 3.1.1 To mention at least two relationships between humans and their environments, with the sense } \\
\text { of caring }\end{array}$ \\
\hline & 3.1.2 To mention at least three environmental benefits for the humans' life \\
\hline & $\begin{array}{l}\text { 4.1.1 To create a mind-map about the interrelatedness between the humans and their environments, } \\
\text { with the sense of responsibility }\end{array}$ \\
\hline \multirow{3}{*}{$\begin{array}{l}\text { Bahasa } \\
\text { Indonesia }\end{array}$} & 3.3.1 To mention at least three procedures for interview \\
\hline & 4.3.1 To sort out a series of questions used for interview about the usage of electricity for daily life \\
\hline & 4.3.2 To put into practice interview with respect to the usage of electricity as the source of energy \\
\hline
\end{tabular}

\section{Developing Preliminary Form of the Product:-}

The instructional media under development was created from wood with the dimension of $40 \mathrm{x} 80 \mathrm{~cm}$. It was in the form of miniatures of mounts, streets, urban buildings, houses, farmlands, and so forth. In addition, it was also voice-assisted to tell the plot of the materials served in the media. The voice was produced from a speaker attached to the backhand of the media. The main product is illustrated in Figure 1 and 2. The interactive instructional media Takbulta which had been developed was validated by the expert of instructional media, the expert of instructional material, and the educational practitioners.

Based on the validation from the expert of instructional media, the percentage was shown to be $94.2 \%$ categorized as "Strongly Valid" with no revision. In accordance with the first validation from the expert of instructional material, the result signified $66.6 \%$ categorized as "Valid" with few revisions. After revision, the second result was shown to be $83.3 \%$ categorized as "Strongly Valid" with no revision. It could be concluded that the instructional media was applicable for use. With reference to the validation result from the educational practitioner 1 and 2 , the percentage showed $94.2 \%$ characterized as "Strongly Valid".

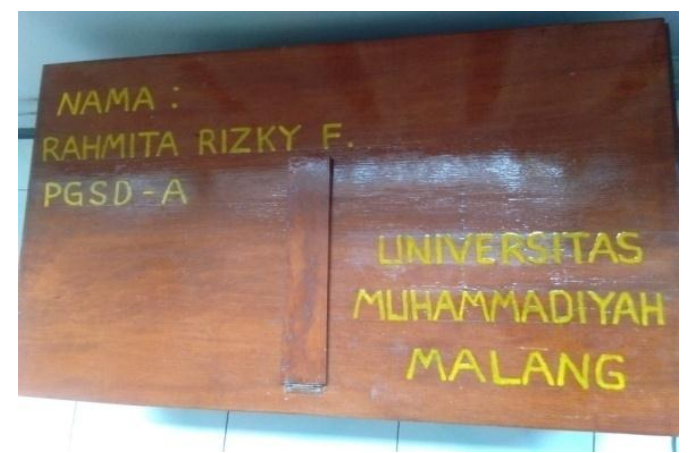

Figure 1:-The Illustration of Outer Look of Takbulta

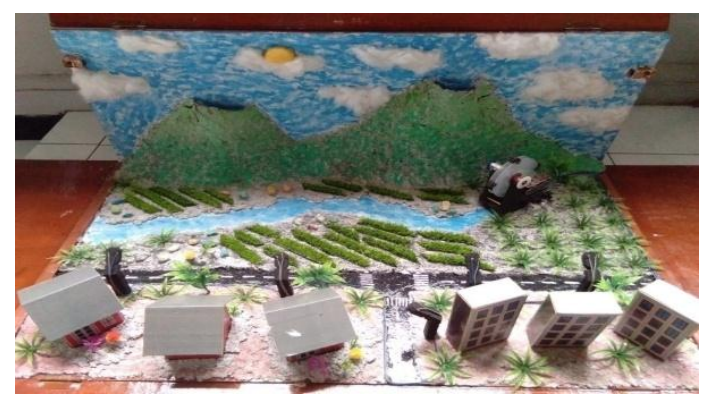

Figure 2:-The Illustration of Inner Look of Takbult 


\section{Preliminary Field Testing:-}

The revised version of the instructional media was tested on the instructional activities. It was shown that the students were more enthusiastic during the session. The instruction turned out to be more active as the students were full of spirit. The students stated that they were very happy to use Takbulta as the instructional media for they felt motivated to be more active to direct questions, give answer, and be active during the instruction.

\section{Main Product Revision:-}

Alluding to preliminary field testing, the instructional media has been considered 'good'. The students said that the instructional media was appropriate for the instruction. By then, major revision on the instructional media was not an urgency.

\section{Main Field Testing:-}

In this phase, with the whole students in classroom as participants, all run very well as in the previous testing (Figure 3). The result of this phase showed that the instruction was running more actively than that of the previous session due to Takbulta media. Those who used to be reluctant and inactive during the instruction became more active and keener on learning. Referring to the data analysis on the filled-up questionnaire, there was merely one item categorized as 'valid'; while the other 16 were characterized as 'strongly valid'.

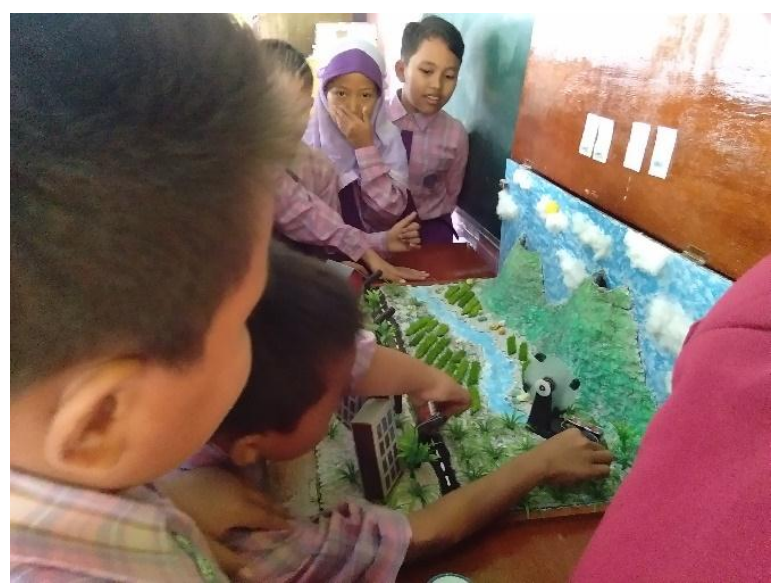

Figure 3:-Main field testing of Takbulta media

\section{Operational Product Revision:-}

In accordance with the previous stage, major revision on the instructional media was not of crucial necessity. However, in this phase of revision, there would be minor betterment on the waterwheel miniature so that it could be rotating as expected.

\section{Operational Field Testing:-}

With respect to the observational result, in this phase, the implementation of the instructional media has boosted the students' motivation in learning and motivated them to always be curious. In addition, they were also shown to be active in group work in addition to directing question and giving answer during the instruction. The questionnaire result has also illustrated that out of 17 items, all of which have characterized 'strongly valid' with the lowest percentage signifying $83.3 \%$.

\section{Final Product Revision:-}

Revision was made based on the suggestion that the number of vehicles in the instructional media be added. In addition, another suggestion to take into account was that the speaker attached to the media be removed to easily insert a memory slot in it. On the other hands, the teachers commented that they did not find any difficulty to use the media; yet it was suggested that instructions for media usage be attached.

In this current research, an innovative 3D instructional media with audio has been developed. The application of the media during instructional activities has shown that it could give positive impacts to the success of instruction. This finding is in line with some previous researches which were also discussing the impacts of instructional media to the success of instruction (Alqahtani \& Mohammad, 2015; Lee, 2015). The positive impacts in this case refers to the 
fact that the application of Takbulta has been able to improve the students' active participatory. Further, such active participatory is closely related to the students' desire to get engaged in the instruction. The high level of the students' active participatory is also closely interlinked to the increase of the students' motivation level for learning. As reported by previous researches, the availability of instructional media could improve students' engagement and motivation during instructional activities. (Muteheli, 2017; Naz \& Akbar, 2010)

Takbulta has been characterized as an instructional media which combines audio and visual aspects which in turn is supposed to be interesting instructional media. The combination of audio and visual media with the touch of 3D would facilitate the students' comprehension on the information they are about to learn (Nugrahani, 2007; Vavra et al., 2011). It is due to the fact that instructional media is believed to be able to illustrate and bridge information to students (Arguel \& Jamet, 2009). For that reason, the availability of this instructional media is also supposed to ease the students to really understand what they are learning about. (Olube, 2015; Pan \& Pan, 2009).

In addition to the benefits for the instruction, the availability of instructional media is said as the most essential component for instruction, especially when the instruction is piloted in primary school level. Students in primary school level belong to the group of individuals whose cognitive development is still at concrete operational level (Astuti, 2018; Ghazi \& Ullah, 2015; Simatwa, 2010). Therefore, it is of essence to generate a specific instructional media which could help students hypothesize abstract and unimaginable concepts. In the same logic, some studies have also reviewed some issues related to the implementation and usage of instructional media in primary school level (Cheng \& Weng, 2017; Mupa \& Chinooneka, 2015; Rolluqui, 2013). Accordingly, Takbulta has been developed in this current research in hope that it could be an effective alternative for teachers to teach in primary school level.

\section{Conclusion:-}

Instructional media is an essential component for instruction, including in primary school level. In this research, a specific instructional media has been developed, named as Takbulta - which combines audio and visual media and is in 3 dimensional form and designed for thematic instruction. Further, the media is focused on sub-theme 'Potential Sources of Energy in Indonesia' which has been proved to be able to improve the active participatory of the fourth graders. Henceforth, Takbulta is recommended to be used during instructional activities in primary schools in broader scope. In addition, it is suggested that other forms of instructional media for thematic instruction be developed on upcoming researches due to the lack of thematic instructional media, all this time.

\section{References:-}

1. Ain, N. (2017). Holistic thematic learning in the elementary school: Is it thematic and holistic? Advances in Social Science, Education and Humanities Research (ASSEHR), 158(ICTTE), 919-928. Retrieved from https://download.atlantis-press.com/article/25885805.pdf

2. Ain, N., \& Rahutami, R. (2018). Theme network in thematic learning in elementary school. In Journal of Physics: Conference Series (Vol. 1013). IOP Publishing. https://doi.org/10.1088/1742-6596/1013/1/012065

3. Alqahtani, M., \& Mohammad, H. (2015). Mobile applications' impact on student performance and satisfaction. Tojdel The Online Journal of Distance Education and E-Learning., 14(4), 102-112. Retrieved from https://pdfs.semanticscholar.org/219c/398206ef5d45e4c66a7891cb328b11ce12d2.pdf

4. Arguel, A., \& Jamet, E. (2009). Using video and static pictures to improve learning of procedural contents. Computers in Human Behavior, 25, 354-359. https://doi.org/10.1016/j.chb.2008.12.014

5. Asfani, K., Suswanto, H., \& Wibawa, A. P. (2016). Influential factors of students' competence. World Transactions on Engineering and Technology Education, 14(3), 416-420. Retrieved from http://www.wiete.com.au/journals/WTE\&TE/Pages/Vol.14, No.3 (2016)/13-Wibawa-A.pdf

6. Astuti, N. P. E. (2018). Teacher's instructional behaviour in instructional management at elementary school reviewed from Piaget'S Cognitive Development Theory. SHS Web of Conferences, 42. https://doi.org/10.1051/shsconf/20184200038

7. Beard, V. (2018). A study of the purpose and value of recess in elementary schools as perceived by teachers and administrators. East Tennessee State University. Retrieved from https://dc.etsu.edu/etd/3433

8. Borg, W. R., \& Gall, M. D. (1983). Educational research an introductioon. New York: Longman.

9. Brown, M. C., McNeil, N. M., \& Glenberg, A. M. (2009). Using concreteness in education: Real problems, potential solutions. Child Development Perspectives, 3(3), 160-164. https://doi.org/10.1111/j.17508606.2009.00098.x 
10. Bulent, A. (2015). The influence of self-efficacy and motivational factors on academic performance in general chemistry course: A modeling study. Educational Research and Reviews, 10(4), 453-461. https://doi.org/10.5897/ERR2014.2003

11. Cera, R., Mancini, M., \& Antonietti, A. (2013). Relationships between metacognition, self-efficacy and selfregulation in learning. ECPS - Educational, Cultural and Psychological Studies, (7), 115-141. https://doi.org/10.7358/ecps-2013-007-cera

12. Cheng, Y., \& Weng, C. (2017). Factors influence the digital media teaching of primary school teachers in a flipped class: A Taiwan case study. South African Journal of Education, 37(1), 1-12. https://doi.org/10.15700/saje.v37n1a1293

13. Doğan, Y., \& Sezer, G. O. (2010). A study on learning environments of elementary school students taking social studies course: Bursa sample. Procedia - Social and Behavioral Sciences, 2(2), 1356-1361. https://doi.org/10.1016/j.sbspro.2010.03.200

14. Ekundayo, H. T. (2012). School facilities as correlates of students' achievement in the affective and psychomotor domains of learning. European Scientific Journal, 8(6), 208-215. Retrieved from https://eujournal.org/index.php/esj/article/download/112/117

15. Fauzi, A., Corebima, A. D., \& Zubaidah, S. (2016). The utilization of ferns as a model organism for studying natural polyploidization concept in genetics course. In International Conference on Education (pp. 51-58). Malang: Universitas Negeri Malang. Retrieved from http://pasca.um.ac.id/conferences/index.php/ice/article/download/11/8

16. Fauzi, A., \& Ramadani, S. D. (2017). Learning the genetics concepts through project activities using Drosophila melanogaster: A qualitative descriptive study. JPBI (Jurnal Pendidikan Biologi Indonesia), 3(3), $238-247$. https://doi.org/10.22219/jpbi.v3i3.4540

17. Ghazi, S. R., \& Ullah, K. (2015). Concrete operational stage of Piaget's Cognitive Development Theory: An implication in learning general science. Gomal UniversityJournal Of Research (GUJR), 31(1), 1019-8180. Retrieved from http://www.gu.edu.pk/New/GUJR/Online_PDF_June_2015/8- CONCRETE OPERATIONAL STAGE OF PIAGETS COGNITIVE DEVELOPMENT THEORY.pdf

18. Gunuc, S. (2014). The relationships between student engagement and their academic achievement. International Journal on New Trends in Education and Their Implication, 5(4), 216-231. Retrieved from http://www.ijonte.org/FileUpload/ks63207/File/19..gunuc.pdf

19. Habibullah, S., \& Ashraf, J. (2013). Factors affecting academic performance of primary school children. Pakistan Journal of Medical Research, 52(2), 47-52. https://doi.org/10.1073/pnas.75.9.4194

20. Hamruni, H., \& Istiningsih, D. (2017). The analysis of material presentation and assessment of thematic learning at State 1 Primary School Sleman Yogyakarta. IOSR Journal of Humanities and Social Science, 22(05), 23-37. https://doi.org/10.9790/0837-2205092337

21. Hasbullah, A., Yusoff, W. Z. W., Ismail, M., \& Vitasari, P. (2011). A framework study of school facilities performance in public primary school of Batubara district in Indonesia. Procedia - Social and Behavioral Sciences, 15, 3708-3712. https://doi.org/10.1016/j.sbspro.2011.04.360

22. Hayes, D. (2010). Encyclopedia of primary education. Oxon: Routledge.

23. Ismael, H. A. (2015). The role of metacognitive knowledge in enhancing learners autonomy. International Journal of Language and Linguistics, 2(4), 95-102.

24. Jony, S. (2016). Student centered instruction for interactive and effective teaching learning: Perceptions of teachers in Bangladesh. International Journal of Advanced Research in Education \& Technology (IJARET, 3(3), 1-7. Retrieved from http://ijaret.com/wp-content/themes/felicity/issues/vol3issue3/mdsolaiman.pdf

25. Knippels, M.-C. P. J. (2002). Coping with the Abstract and Complex Nature of Genetics in Biology Education: The yo-yo learning and teaching strategy. Utrecht: CD- $\beta$ Press.

26. Kui Xie, Vance Durrington; Yen, L. L. (2011). Relationship between students' motivation and their participation in asynchronous online discussion. Journal of Online Learning and Teaching7.1(Mar 2011): 17., 7(March), 17-29. Retrieved from http://jolt.merlot.org/vol7no1/xie_0311.pdf

27. Lee, M. K. (2015). Effects of mobile phone-based app learning compared to computer-based web learning on nursing students: pilot randomized controlled trial. Healthcare Informatics Research, 21(2), 125-133. https://doi.org/10.4258/hir.2015.21.2.125

28. Lindsay, P. (2011). Abstract teaching for a concrete world: A lesson from plato. PS - Political Science and Politics, 44(3), 605-610. https://doi.org/10.1017/S1049096511000692

29. Manjale, N. B., \& Abel, C. (2017). Significance and adequacy of instructional media as perceived by primary school pupils and teachers in Kinondoni District, Tanzania. Original Research Article, 4(6), 151-157. https://doi.org/10.15739/IJEPRR.17.016

30. Merrell, C., \& Thymms, P. (2012). Working with difficult children inprimary schools: A guide for teachers. Durham: Centre for Evaluation \& Monitoring. Retrieved from http://www.cem.org/attachments/publications/ADHD Guide 2013.pdf

31. Mupa, P., \& Chinooneka, T. I. (2015). Factors contributing to ineffective teaching and learning in primary schools : 
why are schools in decadence? Journal of Education and Practice, 6(19), 125-133. Retrieved from https://files.eric.ed.gov/fulltext/EJ1079543.pdf

32. Muteheli, A. F. (2017). A survey of the use of instructional media in teaching oral Literature in Secondary schools in Bungoma South Sub-County, Kenya. International Journal of Scientific and Research Publications, 7(8), $265-268$. Retrieved from http://www.ijsrp.org/research-paper-0817/ijsrp-p6831.pdf

33. Naz, A. A., \& Akbar, R. A. (2010). Use of media for effective instruction its importance: Some consideration. Journal of Elementary Education, 18(1-2), 35-40. https://doi.org/10.20472/TE.2015.3.3.002

34. Nugrahani, R. (2007). Media pembelajaran berbasis visual berbentuk permainan ular tangga untuk meningkatkan kualitas belajar mengajar di sekolah dasar. Lembaran Ilmu Kependidikan, 36(1), 351-44. Retrieved from https://journal.unnes.ac.id/nju/index.php/LIK/article/download/524/481

35. Okoro, C. ., \& Okoro, C. U. (2016). Teachers' understanding and use of thematic approach in teaching and learning of social studies in Rivers State. International Journal of Education, Learning and Development, 4(3), 64-69. Retrieved from http://www.eajournals.org/wp-content/uploads/Teachers----Understanding-and-Use-of-ThematicApproach-in-Teaching-and-Learning-of-Social-Studies-in-Rivers-State1.pdf

36. Olube, F. K. (2015). Primary school pupils' response to audio-visual learning process in Port-Harcourt. Journal of Education and $\quad$ Practice, 6(10), $118-123 . \quad$ Retrieved from http://search.proquest.com/docview/1773231426?accountid=13042

37. Pan, Y., \& Pan, Y. (2009). The effects of pictures on the reading comprehension of low-proficiency Taiwanese English foreign language college students : an action research study. VNUJournal of Science, Foreign Languages, 25 , 186-198. Retrieved from http://tapchi.vnu.edu.vn/nn_3_09/b.8.pdf

38. Puspitasari, P., Putri, P. S. J., \& Wuryani, W. (2018). Pengaruh penggunaan media pembelajaran terhadap motivasi belajar mahasiswa IKIP Siliwangi. Parole: Jurnal Pendidikan Bahasa Dan Sastra Indonesia, 1(2), $227-232$. https://doi.org/http://dx.doi.org/10.22460/p.v1i2p\%25p.243

39. Rajendra, M. I., \& Sudana, M. I. (2018). The influence of interactive multimedia technology to enhance achievement students on practice skills in mechanical technology. In Journal of Physics: Conference Series (Vol. 953, pp. 0-5). IOP Publishing. https://doi.org/10.1088/1742-6596/953/1/012104

40. Rasul, S., \& Bukhsh, Q. (2011). A study of factors affecting students' performance in examination at university level. Procedia - Social and Behavioral Sciences, 15, 2042-2047. https://doi.org/10.1016/j.sbspro.2011.04.050

41. Rolluqui, G. V. (2013). The instructional media for different levels in the Philippine educational system. In ICoME: International Conference for Media in Education (Vol. 4, pp. 556-562). Okuda. Retrieved from http://icome2013.iwd.jp/program/pdf/1p_PDF/A01.pdf

42. Romanova, A. (2016). Discipline and personal formation of elementary school pupils. NORD University. Retrieved from https://brage.bibsys.no/xmlui/bitstream/handle/11250/2437230/Romanova_masteroppgave.pdf?sequence=1

43. Saeed, S., \& Zyngier, D. (2012). How motivation influences student engagement: A qualitative case Study. Journal of Education and Learning, 1(2), 252-267. https://doi.org/10.5539/jel.v1n2p252

44. Simatwa, E. M. W. (2010). Piaget's theory of intellectual development and its implication for instructional management at pre- secondary school level. Educational Research and Reviews, 5(7), 366-371. Retrieved from https://academicjournals.org/article/article1379610138_Simatwa.pdf

45. Smit, K., de Brabander, C. J., \& Martens, R. L. (2014). Student-centred and teacher-centred learning environment in pre-vocational secondary education: Psychological needs, and motivation. Scandinavian Journal of Educational Research, 58(6), 695-712. https://doi.org/10.1080/00313831.2013.821090

46. Sugiyono. (2017). Metode penelitian \& pengembangan. Bandung: Alfabeta.

47. Tessier, L., Suny, D., Tessier, J., \& Delhi, S. (2015). Title: Theme-based courses foster student learning and promote comfort with learning new material. Journal Issue: Journal for Learning through the Arts, 11(1). https://doi.org/10.5811/westjem.2011.5.6700

48. Tomljenovi, Z., \& Novakovi, S. (2012). Integrated teaching - A project in primary school elective art classes. Metodički Obzori, 7(1), 119-134. Retrieved from https://hrcak.srce.hr/file/117131

49. Vavra, K. L., Janjic-watrich, V., Loerke, K., Phillips, L. M., Norris, S. P., \& Macnab, J. (2011). Visualization in science education. ASEJ, 41(1), 22-30. https://doi.org/10.1007/1-4020-3613-2

50. Veiga, F. H., Burden, R., Appleton, J., Taveira, C., \& Galvão, D. (2104). Student's engagement in school: Conceptualization and relations with personal variables and academic performance. Revista de Psicología y Educación, 9(1), 29-47. Retrieved from http://www.revistadepsicologiayeducacion.es/pdf/100.pdf

51. Widiansyah, A. T., Indriwati, S. E., Munzil, \& Fauzi, A. (2018). I-invertebrata as an android-based learning media for molluscs, arthropods, and echinoderms identification and its influence on students' motivation. JPBI (Jurnal Pendidikan Biologi Indonesia), 4(1), 43-52. https://doi.org/10.22219/jpbi.v4i1.5476. 